\title{
Perkembangan Pengaturan Kualitas Udara di Indonesia: dari Pendekatan Tradisional Atur dan Awasi ke arah Bauran Kebajikan
}

\author{
Cecep Aminudin ${ }^{1}$
}

\begin{abstract}
Abstrak
Masalah pencemaran udara membutuhkan respon pengaturan hukum seiring dengan meningkatnya tantangan yang dihadapi. Artikel ini bertujuan untuk menggambarkan perkembangan pengaturan kualitas udara sejak Indonesia merdeka tahun 1945. Uraian dilakukan berdasarkan hasil analisis yuridis normatif terhadap bahan hukum primer dan sekunder yang berhasil diinventarisasi. Perkembangan pengaturan dibagi dalam 5 kurun waktu. Pada periode pertama (1945-1972), ordonansi gangguan merupakan instrumen pengaturan utama. Periode kedua (1972-1982) merupakan tahap perkembangan pertama yang ditandai dengan inisiatif provinsi seperti DKI Jakarta dan Jawa Barat yang menerbitkan peraturan tentang baku mutu udara ambien dan baku mutu emisi. Periode ketiga (1982-1997) merupakan tahap perkembangan kedua yang ditandai dengan pengaturan mengenai baku mutu udara ambien, emisi dan gangguan nasional, serta pengaturan mengenai pedoman teknis. Periode keempat (19972009) ditandai dengan upaya pertama sistematisasi pengaturan dalam Peraturan Pemerintah Nomor 41 Tahun 1999. Periode kelima (2009-sekarang) merupakan momentum untuk mengembangkan pengaturan kualitas udara yang lebih komprehensif. Selama lima periode itu, instrumen kebijakan yang diterapkan

1 Pengamat, pengajar dan konsultan hukum lingkungan, mengampu mata kuliah kebijakan dan hukum lingkungan pada Program Studi Teknik Lingkungan, Fakultas Teknik Sipil dan Lingkungan, Institut Teknologi Bandung sejak 2009, S1 Ilmu Hukum dan S2 Ilmu Lingkungan keduanya dari Universitas Indonesia.
\end{abstract}


telah bergeser dari pendekatan tradisional atur dan awasi kearah bauran kebijakan dengan menerapkan berbagai instrumen lainnya.

Kata Kunci: pencemaran udara, kualitas udara, perkembangan pengaturan, instrumen kebijakan.

\section{Abstract}

Air pollution problems require a response of legal rules along with the increasing challenges faced. This article aims at describing the development of air quality regulation since Indonesia's independence in 1945. The description is based on the results of juridical normative analysis of the primary and secondary legal materials which can be inventoried. The development is divided into 5 periods. In the first period (1945-1972), the disturbance ordinance is the main instrument. The second period (1972-1982) is the first stage of development characterized by local initiatives such as the provinces of Jakarta and West Java which issued a regulation on the ambient air and emission quality standards. The third period (1982-1997) is the second stage of development characterized by regulations regarding national ambient air, emissions and disturbance quality standards, and regulations for technical guidance. The fourth period (1997-2009) marked the first attempt to systematize the regulations in Government Regulation No. 41 Year 1999. The fifth period (2009-present) is a momentum to develop more comprehensive air quality regulations. During those five periods, the application of policy instruments has shifted from a traditional command and control approach to policy mixes by applying a variety of other instruments.

Keywords: air pollution, air quality, regulations development, policy instrument.

\section{Pendahuluan}

Masalah pencemaran udara membutuhkan respon pengaturan hukum seiring dengan meningkatnya tantangan yang hadapi. Tantangan yang dihadapi utamanya terkait dengan meningkatnya emisi dari sumber pencemar udara yaitu transportasi, kegiatan industri, pembuangan dan pembakaran sampah dan kegiatan domestik rumah tangga. ${ }^{2}$ Selain itu, kebakaran hutan dan lahan juga menjadi sumber

2 Moestikahadi Soedomo, Kumpulan Karya Ilmiah Mengenai Pencemaran Udara (Bandung: Penerbit ITB, 1999). Hal 4-5. 


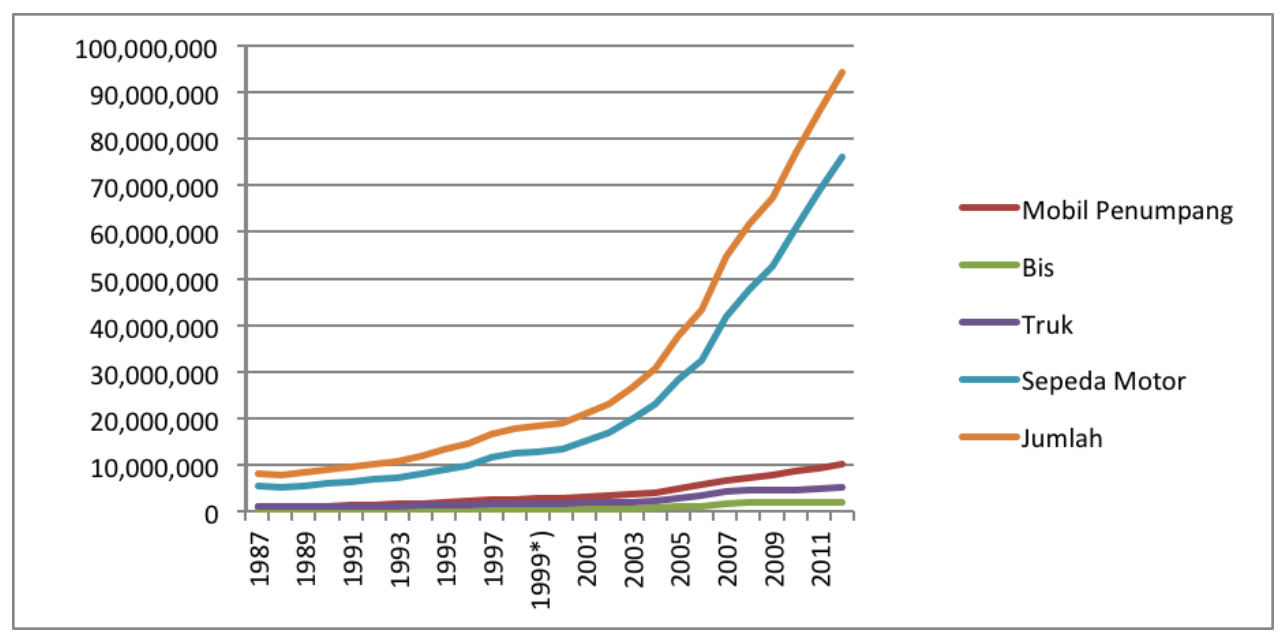

Gambar 1 Perkembangan Jumlah Kendaraan Bermotor di Indonesia (1987-2013) ${ }^{4}$

Pada grafik terlihat peningkatan jumlah kendaraan bermotor yang sangat signifikan, khususnya pada jenis sepeda motor yang meningkat lebih dari 13 kali lipat atau berjumlah sekitar 5 juta pada tahun 1987 menjadi lebih dari 76 juta pada tahun 2012. Sementara itu kendaraan angkutan umum seperti bis peningkatannya lebih rendah yaitu 7 kali lipat dari sekitar 300.000 pada tahun 1987 menjadi sekitar 2.200.000 pada tahun $2012 .^{5}$

Melalui artikel ini penulis mencoba menggambarkan perkembangan pengaturan kualitas udara sejak Indonesia merdeka tahun 1945 hingga saat ini. Uraian dilakukan berdasarkan hasil analisis juridis normatif terhadap bahan hukum primer dan sekunder yang berhasil diinventarisasi serta sumber pustaka lainnya yang berhasil ditelusuri. Perkembangan pengaturan dibagi dalam 5 kurun waktu yang pada masing-masing kurun waktu ditandai dengan momen penting (milestone).

Istilah "pengaturan" sebenarnya mengacu pada pengertian yang lebih komprehensif yang meliputi mata rantai peraturan perundang-undangan,

3 Ibid.

4 Kantor Kepolisian Republik Indonesia sebagaimana dikutip "Badan Pusat Statistik," http://www.bps.go.id/linkTabelStatis/view/id/1413. Diakses pada 3 Mei 2016. *) sejak 1999 tidak termasuk Timor-Timur.

5 Kantor Kepolisian Republik Indonesia sebagaimana dikutip Ibid. 
penentuan standar, pemberian izin, penerapan dan penegakan hukum. ${ }^{6}$ Namun tulisan ini hanya terbatas pada peraturan perundang-undangan, sebagai sumber hukum formil yang berfungsi untuk mengatur atau mempengaruhi perilaku subyek hukum. Materi muatan suatu peraturan lingkungan dapat diidentifikasi berdasarkan instrumen kebijakan lingkungan yang digunakannya. Dalam literatur, terdapat berbagai usaha untuk mengklasifikasikan instrumen kebijakan lingkungan. ${ }^{7}$ Untuk kepentingan penulisan ini digunakan klasifikasi yang dilakukan oleh Organization for Economic Cooperation and Development (OECD) ${ }^{8}$ yang membagi instrumen kebijakan lingkungan menjadi 6 jenis yaitu: atur dan awasi (command and control-CAC), instrumen ekonomi (economic instrument), tanggung gugat dan kompensasi (liability and damage compensation-LDC), pendidikan dan informasi (education and information-EEI), pendekatan sukarela (voluntary approach$V A)$, dan manajemen serta perencanaan (management and planning-MEP). Selain itu, kebijakan untuk merespon permasalahan pencemaran udara yang komprehensif dapat berupa respon kebijakan terhadap faktor pemicu (driving forces), kebijakan untuk mengatasi tekanan (pressure), kebijakan untuk mengatasi kondisi kualitas udara (state), atau kebijakan untuk mengatasi dampak (impact) yang sudah terjadi. Pendekatan ini dikenal dengan nama pendekatan DPSIR (driving force - pressurestate-impact-response). ${ }^{9}$

Pokok permasalahan yang dicoba diulas dalam tulisan ini adalah: (a) faktor apa saja yang mempengaruhi perkembangan pengaturan kualitas udara di Indonesia? (b) bagaimana kecenderungan pergeseran instrumen kebijakan dalam peraturan pengelolaan kualitas udara yang digunakan dari satu periode ke periode berikutnya? (c) sejauh mana kebijakan yang dimuat dalam peraturan bersifat komprehensif (merespon faktor pemicu, tekanan, kondisi dan dampak pencemaran udara)?

6 Andi Hamzah, Penegakan Hukum Lingkungan (Jakarta: Sapta Arta Jaya, 1997). Hal 82.

7 Mengenai hal ini lihat Åsa Maria Persson, "Choosing Environmental Policy Instruments: Case Studies Of Municipal Waste Policy In Sweden And England" (A thesis submitted to the Department of Geography and Environment of the London School of Economics and Political Science for the degree of Doctor of Philosophy, 2007). Hal 36 - 55.

8 OECD, Sustainable Development Critical Issues: Critical Issues (OECD Publishing, 2001).Hal 132.

9 S.G. Vaz, T. Ribeiro, and EEA, Reporting on Environmental Measures: Are We Being Effective?, Environmental Issue Report (European Environment Agency, 2001), http://www.eea. europa.eu/publications/rem/issue25.pdf.hal 21. 


\section{Periode 1945 - 1972: Periode Permulaan}

Pada periode ini dapat dicatat masih berlakunya Ordonansi Gangguan (Hinderordonnantie) warisan pemerintah kolonial Belanda. Jenis pencemar yang tercakup dalam peraturan tersebut adalah asap dan kebauan dengan instrumen utama berupa izin. Izin diwajibkan untuk pendirian bangunan-bangunan tempat bekerja tertentu yang berpotensi menimbulkan gangguan dan dikeluarkan oleh Pemerintah Kabupaten/Kota. Jadi yang diatur lebih kepada jenis usaha/ kegiatannya. ${ }^{10}$ Pada periode ini dapat dikatakan ordonansi ini merupakan instrumen pengaturan utama untuk masalah pencemaran lingkungan termasuk pencemaran udara, khususnya dari sumber tidak bergerak. Namun karena cakupan pengaturannya yang terlalu umum dan kurang jelas jenis pencemaran yang diaturnya, peraturan ini kurang memadai untuk mengendalikan pencemaran. Meskipun demikian, rezim Ordonansi Gangguan warisan kolonial Belanda ini masih berlaku hingga sekarang dan belum pernah dicabut. Sebuah ordonansi dapat dicabut dengan Undang-Undang, meskipun ordonnantie tidak dapat diterjemahkan sebagai Undang-Undang. ${ }^{11}$

Pada periode ini juga dapat dicatat inisiatif Pemerintah DKI Jakarta yang mengeluarkan Peraturan Daerah No. 12 Tahun 1971 tentang Larangan Pengotoran Udara, Air, dan Lepas Pantai dalam Wilayah DKI Jakarta, yang masih berlaku berlaku hingga sekarang. ${ }^{12}$ Namun demikian, tidak banyak yang bisa dicatat pada periode permulaan ini selain pemberlakukan peraturan lama warisan kolonial dan eksperimentasi pengaturan oleh daerah dengan pendekatan CAC (melalui izin gangguan dan larangan). Kebijakan juga tampaknya masih diarahkan hanya pada sebagian tekanan (pressures) yaitu dari sumber tidak bergerak.

10 Undang-Undang Gangguan (Hinderordonnantie) Hinder Ordonnantie Staatsblad Tahun 1926 Nomor 226, 1926. Yang diubah/ditambah terakhir dengan stbl. 1940 No. 450) Pasal 1.

11 Alasannya karena ordonantie merupakan produk penjajahan Belanda sedangkan UndangUndang merupakan produk negara merdeka. Lihat Koesnadi Hardjasoemantri, Hukum Tata Lingkungan, 8th ed. (Yogyakarta: Gadjah Mada University Press, 2009). Hal 66.

12 Lihat Surat Keputusan Gubernur Propinsi DKI Jakarta No. 670/2000 Tanggal 28 Maret 2000 Tentang Penetapan Baku Mutu Emisi Sumber Tidak Bergerak Di Propinsi DKI Jakarta, 2000. yang menyebutkan peraturan ini dalam konsideransnya. Namun penulis belum berhasil mendapatkan teks peraturan ini hingga artikel ini ditulis. 


\section{Periode 1972 - 1982: Tahap Perkembangan Awal dengan Inisiatif Daerah}

Periode ini ditandai dengan Konferensi Perserikatan Bangsa-Bangsa (PBB) tentang Lingkungan Hidup Manusia yang diselenggarakan pada bulan Juni 1972 di Stockholm, Swedia dimana Indonesia ikut hadir sebagai peserta konferensi. Konferensi tersebut menghasilkan di antaranya Deklarasi Stockholm dengan 26 butir prinsip pengelolaan lingkungan hidup global. ${ }^{13}$ Tindak lanjut dari keikutsertaan Indonesia dalam Konferensi tersebut adalah dikeluarkannya Keputusan Presiden Nomor 60 Tahun 1972 tentang Pembentukan Panitia Perumus dan Rencana Kerja bagi Pemerintah di Bidang Pengembangan Lingkungan Hidup.

Pada periode ini dapat dicatat terbitnya Keputusan Menteri Perindustrian No.12/M/SK/1/78 Tentang Pencegahan dan Penanggulangan Pencemaran Lingkungan Sebagai Akibat Dari Usaha Industri. Pertimbangan penerbitan Keputusan Menteri Perindustrian tersebut adalah "bahwa usaha-usaha industri selain mendatangkan kemakmuran bagi masyarakat dapat mengakibatkan gangguan dan pencemaran tata lingkungan hidup, baik gangguan keseimbangan tanah, gangguan keseimbangan air, gangguan bau-bauan dan kebisingan, maupun pencemaran permukaan tanah, pencemaran air dan udara" dan "peraturan perundangan yang telah ada belum cukup mengatur pencegahan dan penanggulangan masalah pencemaran lingkungan sesuai dengan perkembangan teknologi."14 Keputusan Menteri yang berisi 10 Pasal pengaturan tersebut mendefinisikan pencemaran sebagai, "keadaan yang terjadi karena masuknya zatzat ke dalam tanah, air dan udara, sehingga mengganggu susunan tanah, air dan udara yang mengakibatkan kerusakan kehidupan." Instrumen kebijakan yang digunakan adalah pemberdayaan izin usaha, pengawasan dan sanksi administrasi.

Pada tahun 1980, Tjokropanolo, Gubernur Daerah Khusus Ibukota (DKI) Jakarta waktu itu menerbitkan Keputusan Gubernur DKI Jakarta No. 587 Tahun 1980 tentang Penetapan Kriteria Ambient Kualitas Udara dan Kriteria Ambient

13 United Nations, "Report of the United Nations Conference on the Human Environment" (United Nations, 1972), http://www.un-documents.net/aconf48-14r1.pdf.

14 Republik Indonesia, Keputusan Menteri Perindustrian No. 12/M/SK/1/78 Tentang Pencegahan Dan Penanggulangan Pencemaran Lingkungan Sebagai Akibat Dari Usaha Industri, 1978. Lihat bagian konsiderans Keputusan Menteri tersebut. 
Bising dalam Wilayah DKI Jakarta (KepGub DKI 587/1980). Keputusan gubernur tersebut diterbitkan setelah sebelumnya dibentuk Tim Peneliti dan Penyusunan Kriteria Kualitas Udara dan Bising dalam wilayah DKI Jakarta berdasarkan Keputusan Gubernur DKI Jakarta No. 542 Tahun 1978 tanggal 16 September 1978. KepGub DKI 587/1980 tersebut mengatur nilai ambang batas untuk jenis pencemar Carbon Monoksida (CO), Sulfur Dioksida (SO2), Nitrogen Oksida (NO), Amonia (NH3), Timah Hitam (Pb), Hidrogen Sulfida (HS), Oxidant, Debu dan Hidrokarbon. Sedangkan derajat kebisingan yang diatur adalah untuk perumahan, industri/ perkantoran, pusat perdagangan, rekreasi dan campuran perumahan/industri. ${ }^{15}$ Sebagai gambaran, pada tahun 1980, jumlah kendaraan di Jakarta mencapai 754.546 unit yang artinya bertambah lebih dari 3 kali lipat dibanding tahun 1970 yang mencapai 222.082 unit. $^{16}$

Pada periode ini juga dapat dicatat terbitnya Surat Keputusan Gubernur Jawa Barat Nomor 660.31/Sk/694/BKPMD/82 tentang Tata Cara Pengendalian dan Kriteria Pencemaran Lingkungan Akibat Industri (Kep Gub Jawa Barat 660.31/Sk/694/BKPMD/82). Keputusan yang ditandatangani oleh H.A. Kunaefi, Gubernur Jawa Barat waktu itu, didalamnya mengatur tentang definisi emisi, kebisingan, kriteria kualitas udara (ambien) dan kriteria kualitas emisi. Apabila KepGub DKI 587/1980 bersifat umum, artinya mencakup sumber pencemar transportasi dan industri, maka KepGub Jawa Barat 660.31/Sk/694/BKPMD/82 hanya mengatur sumber pencemar industri.

Pada periode tahap perkembangan awal ini dapat dikatakan inisiatif regulasi pengaturan kualitas udara yang lebih bersifat teknis lahir dari daerah provinsi. KepGub DKI 587/1980 merupakan peraturan pertama di Indonesia yang mengatur Baku Mutu Udara Ambien. Bahkan penelitian mengenai kualitas udara di kota-kota besar lainnya yang dilakukan Kantor Menteri Negara Pengawasan Pembangunan dan Lingkungan Hidup (PPLH), berbagai Departemen dan Lembaga penelitian

15 Lihat Bagian Lampiran Keputusan Gubernur KDKI Jakarta No. 587 Tahun 1980 Tentang Penetapan Kriteria Ambient Kualitas Udara Dan Kriteria Ambient Bising Dalam Wilayah DKI Jakarta, 1980.

16 Kantor Statistik Propinsi DKI Jakarta, Statistik Kendaraan Bermotor dan Panjang Jalan tahun 1970- 1989, Jakarta dalam Bambang Sukana and Syahrudji Naseh, "Pencemaran Udara Di DKI Jakarta (Review)," Media Litbangkes III, no. 4 (1993): 6-12. 
waktu itu menggunakan peraturan tersebut sebagai acuan. ${ }^{17} \mathrm{Hal}$ ini dapat dipahami karena Kementerian Negara PPLH yang baru dibentuk pada tahun 1978 dengan tugas pokok mengkoordinasikan pengelolaan lingkungan hidup di berbagai instansi pusat maupun daerah masih mempersiapkan perumusan kebijaksanaan nasional pengelolaan lingkungan hidup. ${ }^{18}$ Dengan demikian, dapat dikatakan instrumen kebijakan yang diterapkan pada periode ini masih berupa instrumen CAC namun mulai menerapkan baku mutu emisi, baku mutu udara ambien, izin usaha, pengawasan dan sanksi administrasi. Dengan adanya baku mutu udara ambien, kebijakan juga mulai merespon kondisi (state) kualitas udara.

\section{Periode 1982 - 1997: Tahap Perkembangan Awal Regulasi Nasional}

Periode ini ditandai dengan terbitnya Undang-Undang Nomor 4 tahun 1982 tentang Pokok-pokok Pengelolaan Lingkungan Hidup (UU 4/1982) yang mengatur tentang pengelolaan lingkungan hidup secara umum termasuk pengendalian pencemaran. Meskipun tidak secara spesifik mengatur tentang pencemaran udara, UU 4/1982 mendefinisikan pencemaran lingkungan sebagai, "masuknya atau dimasukannya makhluk hidup, zat, energi dan atau komponen lain ke dalam lingkungan dan atau berubahnya tatanan lingkungan oleh kegiatan manusia atau oleh proses alam, sehingga kualitas lingkungan menjadi kurang atau tidak berfungsi lagi sesuai dengan peruntukannya." UU 4/1982 juga mendefinisikan baku mutu lingkungan sebagai "batas atau kadar makhluk hidup, zat, energi, atau komponen yang ada dan atau unsur pencemaran yang ditenggang adanya dalam suatu sumber daya tertentu sebagai unsur lingkungan hidup. Selanjutnya diatur bahwa perlindungan lingkungan hidup dilakukan berdasarkan baku mutu lingkunganyang diatur dengan peraturan perundang-undangan. ${ }^{19} \mathrm{UU}$ 4/1982 juga mengatur mengenai ganti kerugian dan sanksi pidana bagi pencemar lingkungan. ${ }^{20}$

17 Koesnadi Hardjasoemantri, Hukum Tata Lingkungan. Hal 239.

18 Lihat Keputusan Presiden Republik Indonesia Nomor 35 Tahun 1978 Tentang Perubahan, Keputusan Presiden Nomor 28 Tahun 1978 Tentang Kedudukan, Tugas Pokok, Fungsi, Dan Tatakerja Menteri Negara Penertiban Aparatur Negara, Menteri Negara Pengawasan Pembangunan Dan Lingkungan Hidup, Menteri Negara Riset Dan Teknologi Serta Susunan Organisasi Stafnya, 1978.

19 Lihat Pasal 15, Republik Indonesia, Undang-Undang Nomor 4 Tahun 1982 Tentang PokokPokok Pengelolaan Lingkungan Hidup, 1982.

Ibid. Lihat Pasal 20-22. 
Pada tahun 1985, Menteri Dalam Negeri menerbitkan Peraturan Menteri Dalam Negeri Nomor 1 Tahun 1985 tentang Tata Cara Pengendalian Pencemaran bagi Perusahaan-Perusahaan Yang Mengadakan Penanaman Modal Menurut Undang-undang Nomor 1 Tahun 1967 dan Undang-Undang Nomor 6 Tahun 1968 (Permendagri 1/1985). Permendagri 1/1985 tersebut mendefinisikan limbah sebagai "hasil sampingan dari proses produksi yang tidak digunakan yang dapat berbentuk benda padat, cair, gas, debu, suara, getaran, perusakan dan lain-lain yang dapat menimbulkan pencemaran bilamana tidak dikelola dengan benar." ${ }^{21}$

Pada tahun 1988, Menteri Lingkungan Hidup menerbitkan Keputusan Menteri Negara Kependudukan dan Lingkungan Hidup Nomor: Kep-02/Menklh/I/1988 Tentang Pedoman Penetapan Baku Mutu Lingkungan (KepmenLH 02/1988). Yang menarik dari KepmenLH 02/1988 adalah pertimbangan diterbitkannya peraturan tersebut adalah "sambil menunggu diundangkannya peraturan pemerintah yang mengatur tentang pengendalian pencemaran lingkungan, dipandang perlu untuk menetapkan baku mutu lingkungan sebagai pedoman untuk menetapkan baku mutu lingkungan dalam rangka pengendalian pencemaran lingkungan hidup di daerah." Tampak disadari betul oleh penyusun peraturan tersebut bahwa pengaturan yang ideal untuk pengendalian pencemaran adalah dalam bentuk Peraturan Pemerintah.22 KepmenLH 02/1988 mengatur definisi pencemaran udara, baku mutu udara ambien dan baku mutu emisi. Baku mutu udara (ambien dan emisi sumber bergerak maupun tidak bergerak) kemudian diatur dalam Bab III, Pasal 7 sampai Pasal 10. Dengan demikian dapat dikatakan KepmenLH 02/1988 merupakan peraturan nasional pertama yang mengatur mengenai Baku Mutu Udara Ambien dan Emisi.

Berdasarkan KepmenLH 02/1988, Gubernur menetapkan baku mutu udara ambien untuk provinsi dengan berpedoman pada baku mutu udara ambien nasional dalam Lampiran III Surat Keputusan tersebut. ${ }^{23}$ Setelah ditetapkan baku

21 Lihat Pasal 1 butir 9, Peraturan Menteri Dalam Negeri Nomor 1 Tahun 1985 Tentang Tata Cara Pengendalian Pencemaran Bagi Perusahaan-Perusahaan Yang Mengadakan Penanaman Modal Menurut Undang-Undang Nomor 1 Tahun 196 Dan Undang-Undang Nomor 6 Tahun 1968., 1985.

22 Lihat bagian konsiderans Keputusan Menteri Negara Kependudukan Dan Lingkungan Hidup Nomor: Kep-02/Menklh/I/1988 Tentang Pedoman Penetapan Baku Mutu Lingkungan, 1988.

23 Ibid. Pasal 7 (1). 
mutu udara ambien, Gubernur menetapkan baku mutu udara emisi dengan berpedoman pada baku mutu udara emisi dalam Lampiran IV Surat Keputusan tersebut. ${ }^{24}$ Apabila terdapat hal yang bersifat khusus dalam menetapkan baku mutu udara ambien dan baku mutu udara emisi, Gubernur berkonsultasi dengan Menteri. ${ }^{25}$ Disini terlihat bahwa KepmenLH 02/1988 menegaskan pentingnya baku mutu emisi sebagai usaha untuk mencapai baku mutu udara ambien. Penegasan ini juga terlihat dalam definisi baku mutu emisi pada peraturan tersebut sebagai berikut:

“Baku mutu udara emisi adalah batas kadar yang diperbolehkan bagi zat atau bahan pencemar untuk dikeluarkan dari sumber pencemaran ke udara, sehingga tidak mengakibatkan dilampauinya baku mutu udara ambien." 26

KepmenLH 02/1988 juga mengatur sekilas tentang cara penetapan baku mutu udara ambien provinsi yang ditetapkan dengan memperhitungkan kondisi udara setempat. Untuk mengetahui kondisi udara setempat, Gubernur berkonsultasi dengan Badan Meteorologi dan Geofisika yang pada saat itu berada di bawah Departemen Perhubungan. ${ }^{27}$

Pasal 9 KepmenLH 02/1988 mencoba melahirkan instrumen pengendalian yang baru, meskipun masih memperkuat pendekatan CAC, berupa izin pembuangan limbah gas.Untuk setiap kegiatan yang membuang limbah gas ke udara ditetapkan mutu emisi, dengan pengertian : a) mutu emisi dari limbah gas yang dibuang ke udara tidak melampaui baku mutu udara emisiyang ditetapkan, dan b) tidak mengakibatkan turunnya kualitas udara. ${ }^{28}$ Mutu emisi dari limbah gas yang dibuang ke udara harus dicantumkan secara jelas dalam izin pembuangan limbah gas. ${ }^{29}$

Pada tahun 1995-1996, dibawah kepemimpinan Sarwono Kusumaatmadja, Menteri Negara Lingkungan Hidup pada Kabinet Pembangunan VI (1993-19980)

\footnotetext{
24 Ibid. Pasal 8.

25 Ibid. Pasal 10.

26 Ibid. Pasal 1 butir 8.

27 Ibid. Pasal 7 (2).

28 Ibid. Pasal 9 (1).

29 Ibid. Pasal 9 (2).
} 
diterbitkan beberapa Keputusan Menteri/Kepala Badan Pengendalian Dampak Lingkungan (Bapedal) yang terkait dengan pengendalian pencemaran udara, yaitu pengaturan emisi sumber tidak bergerak, pengaturan emisi sumber bergerak, pengaturan baku tingkat gangguan, dan program langit biru.

Pengaturan Emisi Sumber Tidak Bergerak. Keputusan Menteri/Kepala Bappedal yang terkait dengan emisi sumber tidak bergerak pada periode ini adalah: (1) Keputusan Menteri Negara Lingkungan Hidup No. Kep.13/MENLH/3/1995 tentang Baku Mutu Emisi Sumber Tidak Bergerak (besi dan baja, pulp dan kertas, pembangkit listrik tenaga uap berbahan bakar batu bara, industri semen dan usaha/kegiatan lainnya) ${ }^{30}$; (2) Keputusan Kepala Badan Pengendalian Dampak Lingkungan Nomor Kep-03 /Bapedal/09/1995 Tentang Persyaratan Teknis Pengolahan Limbah Bahan Berbahaya Beracun (di dalamnya mengatur Baku Mutu Emisi Insinerator); (3) sebagai pelaksanaan Kep-13/MENLH/3/1995 kemudian diterbitkan Keputusan Kepala Badan Pengendalian Dampak Lingkungan Nomor 205 Tahun 1996 tentang Pedoman Teknis Pengendalian Pencemaran Udara Sumber Tidak Bergerak (di dalamnya mengatur mekanisme pemantauan kualitas udara, pengambilan contoh uji dan analisis, persyaratan cerobong dan unit pengendalian pencemaran udara).

Analisis Mengenai Dampak Lingkungan (Amdal). Meskipun tidak khusus mengatur pencemaran udara, Amdal adalah salah satu instrumen penting pengendalian pencemaran udara dari sumber tidak bergerak yang bersifat CAC. Sebagai pelaksanaan ketentuan Pasal 16 UU 4/1982, untuk pertama kali pengaturan mengenai teknis pelaksanaan Amdal dituangkan dalam Peraturan Pemerintah Nomor 29 Tahun 1986 Tanggal 5 Juni 1986 (PP 29/1986). PP 29/1986 kemudian disempurnakan dengan Peraturan Pemerintah Nomor 51 Tahun 1993 Tentang Analisis Mengenai Dampak Lingkungan (PP 51/1993). Sebagai pelaksanaan PP 51/1993 kemudian diterbitkan Keputusan Menteri Negara Lingkungan Hidup Nomor: Kep-11/Menlh/3/1994 Tentang Jenis Usaha Atau Kegiatan Yang Wajib Dilengkapi Dengan Analisis Mengenai Dampak Lingkungan, yang kemudian direvisi dengan Keputusan Menteri Negara Lingkungan Hidup Menteri Negara Lingkungan Hidup Nomor: KEP-39/MENLH/8/1996.

30 Peraturan ini mencabut ketentuan mengenai baku mutu emisi sumber tidak bergerak dalam Kep-02/MENKLH/I/1988. 
Pengaturan Emisi Sumber Bergerak. Baku mutu emisi sumber bergerak (kendaraan bermotor) dalam Kep-02/Menklh/I/1988 kemudian direvisi dengan Keputusan Menteri Negara Lingkungan Hidup Nomor: KEP-35/MENLH/10/1993 tentang Ambang Batas Emisi Gas Buang Kendaraan Bermotor (Tipe Baru dan Lama) (KEP35/MENLH/10/1993). Yang menarik dari KEP-35/MENLH/10/1993 adalah dasar pembentukan Kepmen tersebut adalah Peraturan Pemerintah Nomor 44 Tahun 1993 tentang Kendaraan dan Pengemudi yang telah mengatur ketentuan mengenai persyaratan laik jalan kendaraan bermotor yang meliputi antara lain ambang batas emisi gas buang kendaraan bermotor. ${ }^{31}$

Pengaturan Baku Tingkat Gangguan. Pada periode ini juga diterbitkan peraturan menteri tentang baku tingkat gangguan (kebisingan, getaran dan kebauan) yaitu: (a) Keputusan Menteri Negara Lingkungan Hidup Nomor KEP-48/MENLH/11/1996 tentang Baku Tingkat Kebisingan; (b) Keputusan Menteri Negara Lingkungan Hidup Nomor KEP-49/MENLH/11/1996 tentang Baku Tingkat Getaran; (c) Keputusan Menteri Negara Lingkungan Hidup Nomor KEP-50/MENLH/11/1996 tentang Baku Tingkat Kebauan. Ketiga peraturan tersebut masih berlaku hingga sekarang.

Program Langit Biru. Sebagai salah satu upaya pengendalian pencemaran udara dari kegiatan sumber bergerak dan sumber tidak bergerak, pada periode ini Kementerian LH melaksanakan program langit biru yang ditetapkan dengan Keputusan Menteri Negara Lingkungan Hidup (MENLH) Nomor 15 Tahun 1996 tentang Program Langit Biru. Pelaksanaan program ini di daerah melibatkan Bupati/Walikota, Gubernur, Bapedal Wilayah dan Menteri dalam Negeri. Semenjak dileburnya Bapedal ke dalam KLH pada 2002, maka Program Langit Biru menjadi bagian kegiatan dari masing-masing Asisten Deputi MENLH yang menangani urusan pengendalian pencemaran sumber bergerak dan sumber tidak bergerak. Dalam perjalanannya, Program Langit Biru untuk sumber tidak bergerak diintegrasikan dalam kegiatan Penilaian Peringkat Kinerja Perusahaan dalam Pengelolaan Lingkungan Hidup (PROPER).32 Berdasarkan KEP-16/

31 Pasal 7 huruf c dan Pasal 127 ayat (1) a, Peraturan Pemerintah Nomor 44 Tahun 1993 Tentang Kendaraan Dan Pengemudi, 1993.

32 M. Didin Khaerudin et al., Kota Di Persimpangan Jalan: Pedoman Perancangan Strategi Pengendalian Emisi Dari Sektor Transportasi Jalan Di Kawasan Perkotaan (Jakarta: Kementerian Lingkungan Hidup, 2009). Hal 111. 
MENLH/4/1996 ditetapkan Provinsi yang menjadi prioritas program langit biru yaitu DKI Jakarta, Jawa Barat, Jawa Tengah dan Jawa Timur.

Perlindungan fungsi atmosfer. Pada periode ini Pemerintah mengesahkan United Nations Framework Convention on Climate Change dengan Undang-Undang Nomor 6 Tahun 1994. Selain itu, pada periode ini Pemerintah juga mengesahkan Vienna Convention for the Protection of the Ozone Layer dan Montreal Protocol on Substances that Deplete the Ozone Layer as Adjusted and Amended by the Second Meeting of the Parties London, 27 - 29 June 1990 melalui Keputusan Presiden Republik Indonesia Nomor 23 Tahun 1992. Dengan diratifikasinya perjanjian-perjanjian internasional tersebut maka otomatis menjadi bagian dari hukum nasional. ${ }^{33}$

Berdasarkan uraian tersebut dapat dikatakan, periode ini merupakan tahap perkembangan awal regulasi nasional mengenai pengendalian pencemaran udara yang ditandai dengan lahirnya UU 4/1982 dan berbagai peraturan Menteri Lingkungan Hidup/Kepala Bapedal yang terkait dengan pengendalian pencemaran udara. Instrumen kebijakan yang diterapkan masih berupa instrumen CAC dengan memperkuat pengaturan baku mutu emisi, baku mutu gangguan, baku mutu udara ambien, izin usaha, pengawasan, sanksi administrasi, dan sanksi pidana. Penambahan instrumen baru dalam kategori CAC adalah penerapan Amdal dan pengaturan mengenai izin pembuangan limbah gas. Pendekatan LDC juga mulai diterapkan dengan aturan ganti rugi dalam UU 4/1982. Dari sisi cakupan, respon kebijakan tampaknya masih pada aspek tekanan (pressure) dan kondisi (state) kualitas udara, namun jenis pencemar gangguan sudah mulai diatur secara khusus.

\section{Periode 1997 - 2009: Upaya Pertama Sistematisasi Regulasi Nasional}

Periode ini ditandai dengan lahirnya Undang-Undang Nomor 23 tahun 1997 Tentang Pengelolaan Lingkungan Hidup (UU 23/1997) yang menggantikan UU 4/1982. UU 23/1997 memberikan landasan hukum bagi pengaturan mengenai baku mutu lingkungan, Amdal sebagai prasyarat izin usaha/kegiatan, izin

33 Karya tulis yang membahas masalah ini secara komprehensif lihat La Ode Muhammad Syarif, The Implementation of International Responsibilities for Atmospheric Pollution: A Comparison Between Indonesia and Australia (Jakarta: ICEL, 2001). 
pembuangan limbah, audit lingkungan (wajib dan sukarela), pengawasan, sanksi administrasi, perdata (ganti rugi dan strict liability) dan sanksi pidana.

Perkembangan penting pada periode ini adalah terbitnya Peraturan Pemerintah No. 41 Tahun 1999 Tentang Pengendalian Pencemaran Udara (PP 41/1999) sebagai peraturan pelaksanaan dari UU 23/1997. PP 41/1999 terdiri dari IX Bab dan 59 Pasal. Peraturan Pemerintah yang ditandatangani oleh Presiden B.J. Habibie tersebut mengatur mengenai perlindungan mutu udara (baku mutu udara ambien, status mutu udara ambien, baku mutu emisi dan ambang batas emisi gas buang, baku tingkat gangguan dan ambang batas kebisingan, ISPU), pengendalian pencemaran udara (pencegahan dan persyaratan penaatan lingkungan hidup, penanggulangan dan pemulihan (keadaan darurat, sumber tidak bergerak, sumber bergerak, sumber gangguan), pengawasan, pembiayaan, ganti rugi dan sanksi. PP 41/1999 memang menyebutkan sumber emisi terdiri dari sumber bergerak (kendaraan bermotor), sumber bergerak spesifik (kereta api, pesawat terbang, kapal laut dan kendaraan berat lainnya), sumber tidak bergerak (utamanya industri), maupun sumber tidak bergerak spesifik (kebakaran hutan dan pembakaran sampah). Namun demikian, PP 41/1999 juga menegaskan bahwa pengendalian pencemaran udara dari sumber bergerak spesifik dan sumber tidak bergerak spesifik belum diatur lebih lanjut dalam PP 41/1999 karena keterbatasan teknis dalam penyusunan dan pelaksanaannya di lapangan pada saat itu. ${ }^{34}$

Kebakaran Hutan dan Lahan. Untuk merespon masalah pencemaran dan kerusakan lingkungan akibat kebakaran hutan dan lahan yang dampaknya bersifat nasional bahkan lintas batas negara, pemerintah pada masa Presiden Abdurahman Wahid menerbitkan Peraturan Pemerintah RI Nomor 04 Tahun 2001 tentang Pengendalian Kerusakan dan atau Pencemaran Lingkungan Hidup yang Berkaitan dengan Kebakaran Hutan dan atau Lahan. Kebakaran hutan dan atau lahan di Indonesia, terjadi setiap tahun walaupun frekuensi, intensitas, dan luas arealnya berbeda. Kebakaran paling besar terjadipada tahun 1997/1998 di 25 (dua puluh lima) provinsi, yang untuk pertama kali dinyatakan sebagai bencana nasional. ${ }^{35}$

34 Lihat Pasal 2 dan Penjelasan Pasal 2 Peraturan Pemerintah Nomor 41 Tahun 1999 tentang Pengendalian Pencemaran Udara.

35 Lihat Penjelasan Umum Peraturan Pemerintah RI Nomor 04 Tahun 2001 Tentang Pengendalian Kerusakan Dan Atau Pencemaran Lingkungan Hidup Yang Berkaitan Dengan Kebakaran Hutan Dan Atau Lahan, 2001. 
Meskipun ada PP tersendiri mengenai pengendalian kerusakan/pencemaran lingkungan hidup akibat kebakaran hutan dan lahan, namun pengendalian terhadap terjadinya kerusakan dan atau pencemaran lingkungan hidup diatur dalam peraturan perundang-undangan tersendiri, seperti dalam Peraturan Pemerintah tentang Pengendalian Pencemaran Udara dan Peraturan Pemerintah tentang Pengendalian Pencemaran Air. ${ }^{36}$ Baku mutu udara ambien misalnya, tetap mengacu pada PP 41/1999. ${ }^{37}$

Pengaturan Emisi Sumber Tidak Bergerak. Upaya untuk mengatur baku mutu emisi dari sumber tidak bergerak terus dilakukan pada periode ini. Peraturan/ Keputusan Menteri mengenai hal ini yang terbit pada periode ini adalah: (1) Keputusan Menteri Negara Lingkungan Hidup Nomor 133 Tahun 2004 tentang Baku Mutu Emisi Bagi Kegiatan Industri Pupuk; (2) Peraturan Menteri Negara Lingkungan Hidup No. 07 Tahun 2007 Tentang Baku Mutu Emisi Sumber Tidak Bergerak Bagi Ketel Uap; (3) Peraturan Menteri Negara Lingkungan Hidup No. 17 Tahun 2008 Tentang baku Mutu Emisi Sumber Tidak Bergerak Bagi Usaha dan/ atau Kegiatan Industri Keramik; (4) Peraturan Menteri Negara Lingkungan Hidup No. 18 Tahun 2008 Tentang baku Mutu Emisi Sumber Tidak Bergerak Bagi Usaha dan/atau Kegiatan Industri Carbon Black; dan (5) Peraturan Menteri Negara Lingkungan Hidup No. 21 Tahun 2008 Tentang baku Mutu Emisi Sumber Tidak Bergerak Bagi Usaha dan/atau Kegiatan Pembangkit Tenaga Listrik Termal.

Program penilaian peringkat kinerja perusahaan (PROPER) yang pada awalnya diutamakan pada pengendalian pencemaran $\operatorname{air}^{38}$, kemudian juga mencakup pengendalian pencemaran udara dengan diterbitkannya Keputusan Menteri Lingkungan Hidup Nomor 127 Tahun 2002 tentang Program Penilaian Peringkat Kinerja Perusahaan dalam Pengelolaan Lingkungan Hidup. Hal ini menandai digunakannya instrumen kebijakan informasi dalam pengendalian pencemaran udara dari sumber tidak bergerak.

36 Ibid.

37 Ibid. Pasal 9 dan 10.

38 Lihat Keputusan Menteri Negara Lingkungan Hidup Nomor KEP-35 A/MENLH/7/1995 tentang Program Penilaian Kinerja Perusahaan/Kegiatan Usaha Dalam Pengendalian Pencemaran dalam Lingkup Kegiatan PROKASIH (PROPER PROKASIH). 
Amdal. Dengan diundangkannya UU 23/1997, Peraturan Pemerintah Nomor 51 Tahun 1993 tentang Analisis Mengenai Dampak Lingkungan kemudian disesuaikan dan diubah menjadi Peraturan Pemerintah Nomor 27 Tahun 1999 tentang Analisis Mengenai Dampak Lingkungan. Demikian pula Kep-39/MENLH/11/1996 tentang Jenis Usaha Atau Kegiatan yang wajib dilengkapi dengan Analisis Mengenai Dampak Lingkungan diganti dengan Keputusan Menteri LH Nomor 3 Tahun 2000 yang kemudian direvisi lagi dengan KepmenLH 17/2001. KepmenLH 17/2001 kemudian direvisi dengan PermenLH 11/2006.

Pengaturan Emisi Sumber Bergerak. Pengaturan baku mutu emisi sumber bergerak terus ditingkatkan pada periode ini. Ambang Batas Emisi Gas Buang Kendaraan Bermotor untuk uji tipe emisi kendaraan bermotor tipe baru dan kendaraan yang sedang diproduksi (current production) dalam KEP-35/MENLH/10/1993 digantikan dengan Keputusan Menteri Negara Lingkungan Hidup No. 141 Tahun 2003. Sedangkan Ambang Batas Emisi Gas Buang Kendaraan Bermotor Lama dalam KEP-35/MENLH/10/1993 digantikan dengan Peraturan Menteri Negara Lingkungan Hidup No. 05 Tahun 2006. Selain itu untuk meningkatkan penaatan terhadap emisi gas buang kendaraan bermotor tipe baru sebagaimana telah diatur dalam Keputusan Menteri Negara Lingkungan Hidup Nomor 141 Tahun 2003, Menteri Lingkungan Hidup menetapkan Keputusan Menteri Negara Lingkungan Hidup Nomor 252 tahun 2004 tentang Program Penilaian Peringkat Hasil Uji Tipe Emisi Gas Buang Kendaraan Bermotor Tipe Baru. Hal ini menandai digunakannya instrumen kebijakan informasi dalam pengendalian pencemaran udara dari sumber tidak bergerak tipe baru.

Indeks Standar Pencemar Udara (ISPU). Pada periode ini juga mulai diterapkan ISPU dengan pertimbangan "untuk memberikan kemudahan dan keseragaman informasi kualitas udara ambien kepada masyarakat di lokasi dan waktu tertentu" serta "sebagai bahan pertimbangan dalam melakukan upaya-upaya pengendalian pencemaran udara" ${ }^{39}$ Mengenai ISPU ini diatur dalam Keputusan Menteri Negara Lingkungan Hidup Nomor 45 Tahun 1997 tentang Indeks Standar Pencemar Udara yang kemudian dijabarkan dalam Keputusan Kepala Badan Pengendalian Dampak Lingkungan Nomor KEP-107/KABAPEDAL/11/1997 tentang Pedoman Teknis

39 Lihat Bagian konsiderans Keputusan Menteri Negara Lingkungan Hidup Nomor 45 Tahun 1997 Tentang Indeks Standar Pencemar Udara, 1997. 
Perhitungan dan Pelaporan Serta Informasi Indeks Standar Pencemar Udara.

Pengembangan Kapasitas Daerah. Upaya pengembangan kapasitas daerah pada periode ini dilakukan berdasarkan Pasal 11 ayat (4) Undang-Undang Nomor 32 Tahun 2004 tentang Pemerintahan Daerah dan Pasal 8 ayat (1) Peraturan Pemerintah Nomor 38 Tahun 2007 tentang Pembagian Urusan Pemerintahan Antara Pemerintah Pemerintahan Daerah Provinsi, dan Pemerintahan Daerah Kabupaten/Kota, yang menyatakan penyelenggaraan urusan pemerintahan yang bersifat wajib berpedoman pada standar pelayanan minimal yang dilaksanakan secara bertahap dan ditetapkan oleh Pemerintah. Untuk menindaklanjuti ketentuan tersebut, Menteri Lingkungan Hidup menerbitkan Peraturan Menteri Negara Lingkungan Hidup Nomor 19 Tahun 2008 tentang Standar Pelayanan Minimal Bidang Lingkungan Hidup Daerah Provinsi dan Daerah Kabupaten / Kota dan Peraturan Menteri Negara Lingkungan Hidup Nomor 20 Tahun 2008 tentang Petunjuk Teknis Standar Pelayanan Minimal Bidang Lingkungan Hidup Daerah Provinsi dan Daerah Kabupaten / Kota yang di dalamnya mengatur mengenai pelayanan informasi status mutu udara ambien dan pelayanan pencegahan pencemaran udara dari sumber tidak bergerak.

Pemanfaatan ruang dan pengendalian pencemaran udara. Meskipun pengendalian pencemaran udara baik dari sumber bergerak maupun sumber tidak bergerak disadari sangat terkait dengan kegiatan pemanfaatan ruang namun PP 41/1999 belum mengatur atau menyinggung mengenai hal ini. Adalah Undang-Undang Nomor 26 Tahun 2007 tentang Penataan Ruang yang kemudian menyatakan secara eksplisit bahwa pemanfaatan ruang dilaksanakan sesuai dengan standar kualitas lingkungan serta daya dukung dan daya tampung lingkungan. ${ }^{40}$ Keterkaitan

40 Republik Indonesia, Undang-Undang Nomor 26 Tahun 2007 Tentang Penataan Ruang, 2007. Pasal 34 ayat (4) huruf b dan c. Penjelasan Pasal 34 ayat (4) huruf b UU 26/2007 menyatakan sebagai berikut:

\footnotetext{
"Yang dimaksud dengan standar kualitas lingkungan, antara lain, adalah baku mutu lingkungan dan ketentuan pemanfaatan ruang yang berkaitan dengan ambang batas pencemaran udara, ambang batas pencemaran air, dan ambang batas tingkat kebisingan.
}

Penerapan kualitas lingkungan disesuaikan dengan jenis pemanfaatan ruang sehingga standar kualitas lingkungan di kawasan perumahan akan berbeda dengan standar kualitas lingkungan di kawasan industri." 
antara penataan ruang dengan upaya pengendalian pencemaran udara apabila dielaborasi lebih lanjut menandakan digunakannya instrumen kebijakan yang bersifat perencanaan dan manajemen (management and planning).

Perlindungan fungsi atmosfer. Pada tahun 2004 dengan Undang-Undang Nomor 17 Tahun 2004 Indonesia mengesahkanProtokol Kyoto atas Konvensi Kerangka Kerja Perserikatan Bangsa-bangsa tentang Perubahan Iklim. Mengenai perlindungan lapisan ozon, pada periode ini pemerintah juga mengesahkan Montreal Protocol on Substances that Deplete the Ozone Layer, Copenhagen, 1992 (Protokol Montreal tentang Zat-zat yang Merusak Lapisan Ozon, Copenhagen, 1992) melalui Keputusan Presiden Republik Indonesia Nomor 92 Tahun 1998. Selain itu, Kementerian Perdagangan dan Perindustrian juga menerbitkan Keputusan Menteri Perdagangan Nomor 24/M-DAG/ PER/6/2006 tentang Ketentuan Impor Bahan Perusak Ozon dan Peraturan Menteri Perindustrian Nomor 33/M-IND/PER/4/2007 tentang Larangan Memproduksi Bahan Perusak Lapisan Ozon serta Memproduksi Barang yang Menggunakan Bahan Perusak Lapisan Ozon.

Selanjutnya perlu pula dicatat bahwa pada periode ini (sekitar tahun 2006-2007) terdapat inisiatif penyusunan Rancangan Undang-Undang (RUU) Pengelolaan Udara Bersih yang akan merupakan Undang-Undang yang bersifat lex specialis terhadap Undang Undang No.23/1997 tentang Pengelolaan Lingkungan Hidup. Salah satu pertimbangan perlunya disusun peraturan payung mengenai udara adalah karena udara bersifat global. ${ }^{41}$ Namun proses penyusunan RUU ini kemudian terhenti dan yang kemudian lahir adalah Undang-Undang Nomor 32 Tahun 2009 tentang Perlindungan dan Pengelolaan Lingkungan Hidup yang menggantikan UU 23/1997.

Berdasarkan uraian tersebut PP 41/1999 dapat dikatakan sebagai upaya pertama sistematisasi regulasi nasional mengenai pengendalian pencemaran udara dalam bentuk Peraturan Pemerintah. Namun demikian, patut dicatat beberapa kelemahan dari peraturan pemerintah ini yaitu ${ }^{42}$ : (a) belum mengatur secara rinci peran sektor terkait ataupun pemerintah daerah, (b) masih berorientasi

41 “Kesimpulan Kelompok Substansi Udara Bersih," accessed May 3, 2016, http:/ /langitbiru. menlh.go.id/upload/program/pdf/kes-rakor.pdf.

42 Dede Nurdin Sadat et al., Udara Bersih Hak Kita Bersama (Jakarta: Pelangi, 2003). 
pada penanggulangan dan pemulihan ketika baku mutu udara ambien terlampaui namun belum mengatur pencegahan/pemeliharaan ketika baku mutu udara ambien sudah terpenuhi, (c) belum mencantumkan norma dasar dalam penetapan baku mutu udara ambien nasional, (d) belum mengatur pengembangan model dispersi pencemaran udara, (e) masih mengandalkan pada pendekatan command and control, (f) belum mengatur parameter pencemar udara yang bersifat toksik, (g) yang wajib membuat baku mutu udara ambien daerah seharusnya daerah dengan kriteria tertentu.

Instrumen kebijakan yang diterapkan pada periode ini masih berupa instrumen CAC dengan memperkuat pengaturan baku mutu emisi, baku mutu udara ambien, Amdal sebagai prasyarat izin usaha, pengawasan dan sanksi administrasi, serta sanksi pidana. Pendekatan LDC juga diperkuat dengan aturan ganti rugi dan strict liability dalam UU 23/1997. Pendekatan E\&I mulai diterapkan dengan dimasukannya aspek pencemaran udara dalam program PROPER dan program Peringkat Hasil Uji Tipe Emisi Gas Buang Kendaraan Bermotor Tipe Baru. Dengan demikian, pendekatan kebijakan bauran (policy mixes) mulai diterapkan pada periode ini. Dari sisi cakupan kebijakan, respon terhadap tekanan (pressures) ditambahkan dengan respon terhadap sumber pencemar udara dari kebakaran hutan, respon terhadap kondisi (state) kualitas udara diperjelas dengan adanya ISPU dan respon terhadap dampak (impacts) mulai terlihat dengan pengaturan mengenai penanggulangan dan keadaan darurat.

\section{2009 - Sekarang: Menuju Pengaturan Pengelolaan Kualitas Udara yang Lebih Komprehensif?}

Periode ini ditandai dengan lahirnya Undang-Undang Nomor 32 Tahun 2009 tentang Perlindungan dan Pengelolaan Lingkungan Hidup (UU 32/2009) yang menggantikan UU 23/1997. Beberapa Pasal yang terkait dengan Pengelolaan Kualitas Udara dalam UU 32/2009 adalah Pasal 11 mengenai inventarisasi lingkungan hidup, penetapan ekoregion dan Rencana Perlindungan dan Pengelolaan Lingkungan Hidup (RPPLH), Pasal 12 ayat (4) mengenai tata cara penetapan daya dukung dan daya tampung, Pasal 20 ayat (4) mengenai baku mutu udara ambien, Pasal 56 mengenai pengendalian pencemaran, Pasal 
57 ayat (5) mengenai konservasi dan pencadangan sumber daya alam dan pelestarian fungsi atmosfer, Pasal 75 mengenai tata cara pengangkatan pejabat pengawas lingkungan hidup dan tata cara pelaksanaan pengawasan, serta Pasal 83 mengenai sanksi administratif, yang perlu dijabarkan lebih lanjut dalam Peraturan Pemerintah.

Pengendalian Emisi Sumber Tidak Bergerak. Pengendalian emisi sumber tidak bergerak pada periode ini dilakukan dengan melanjutkan pengaturan baku mutu emisi, standar kompetensi penanggungjawab pengendalian pencemaran udara, penilaian peringkat kinerja perusahaan, serta Amdal dan Izin Lingkungan.

Baku Mutu dan Beban Emisi. Pada periode ini dihasilkan 3 peraturan menteri yaitu: (a) Peraturan Menteri Negara Lingkungan Hidup No. 04 Tahun 2014 Tentang Baku Mutu Emisi Sumber Tidak Bergerak Bagi Usaha dan / atau Kegiatan Pertambangan yang mencakup kegiatan pertambangan bijih nikel, bijih bauksit, bijih timah, bijih besi, bijih mineral lainnya dan batubara, (b) Peraturan Menteri Negara Lingkungan Hidup No. 13 Tahun 2009 Tentang Baku Mutu Emisi Sumber Tidak Bergerak Bagi Usaha dan atau Kegiatan Minyak Bumi dan Gas yang kemudian disusul dengan Peraturan Menteri Negara Lingkungan Hidup No. 12 Tahun 2012 Tentang Pedoman Penghitungan Beban Emisi Kegiatan Industri Minyak dan Gas Bumi; dan (c) Peraturan Menteri Negara Lingkungan Hidup No. 07 Tahun 2012 Tentang Pengelolaan Emisi Sumber Tidak Bergerak Bagi Usaha dan / atau Kegiatan Industri Rayon.

Standar Kompetensi Penanggungjawab Pengendalian Pencemaran Udara. Pada periode ini juga perkenalkan instrumen pengendalian pencemaran udara yang baru berupa standar kompetensi sumber daya manusia di bidang pengendalian pencemaran udara dengan diterbitkannya Peraturan Menteri Negara Lingkungan Hidup No. 04 Tahun 2011 Tentang Standar Kompetensi Penanggungjawab Pengendalian Pencemaran Udara.

Penilaian Peringkat Kinerja Perusahaan. Program penilaian peringkat kinerja perusahaan terus dilanjutkan pada periode ini yang antara laian ditandai dengan Peraturan Menteri Lingkungan Hidup RI Nomor 03 Tahun 2014 tentang Program Penilaian Peringkat Kinerja Perusahaan Dalam Pengelolaan Lingkungan Hidup. Penaataan perusahaan terhadap baku mutu emisi tiap parameter pencemar udara 
menjadi salah satu aspek penilaian.

Amdal dan Izin Lingkungan. Peraturan Pemerintah Nomor 27 Tahun 1999 tentang Analisis Mengenai Dampak Lingkungan kemudian dicabut dan digantikan dengan Peraturan Pemerintah Nomor 27 Tahun 2012 tentang Izin Lingkungan. Sementara itu, Peraturan Menteri Negara Lingkungan Hidup No. 05 Tahun 2012 Tentang Jenis Rencana Usaha dan/atau Kegiatan yang Wajib Memiliki Analisis Mengenai Dampak Lingkungan Hidup menggantikan dan mencabut Peraturan Menteri Negara Lingkungan Hidup Nomor 11 tahun 2006. Beberapa jenis kegiatan diwajibkan memiliki Amdal dengan pertimbangan dampaknya terhadap pencemaran udara seperti pembangunan gedung, pembangunan terminal, pembangunan bandar udara, eksploitasi minyak dan gas bumi, ketenagalistrikan, panas bumi dan pengelolaan limbah B3.

Pengaturan Emisi Sumber Bergerak. Pengaturan emisi sumber bergerak pada periode ini dilakukan dengan menyempurnakan pengaturan emisi gas buang kendaraan bermotor dan ambang batas kebisingan kendaraan bermotor.

Emisi Gas Buang. Pada periode ini diterbitkan Peraturan Menteri Negara Lingkungan Hidup No. 04 Tahun 2009 Tentang Ambang Batas Emisi Gas Buang Kendaraan Bermotor Tipe Baru. Selain itu juga diterbitkan Peraturan Menteri Negara Lingkungan Hidup Nomor 10 Tahun 2012 tentang Baku Mutu Emisi Gas Buang Kendaraan Bermotor Tipe Baru Kategori L3 (roda 2) yang kemudian diubah dengan Peraturan Menteri Negara Lingkungan Hidup No. 23 Tahun 2012. ${ }^{43}$

Kebisingan. Peraturan Menteri Negara Lingkungan Hidup No. 07 Tahun 2009 Tentang Ambang Batas Kebisingan Kendaraan Bermotor Tipe Baru. PermenLH ini merupakan pelaksanaan ketentuan Pasal 10 ayat(1), Pasal 41 ayat (3), dan Pasal 42 ayat (3) PeraturanPemerintah Nomor 41 Tahun 1999 tentang Pengendalian Pencemaran Udara.

Pencemar Udara Organik yang Persisten. Pada tahun 2009 Indonesia juga mengesahkan Konvensi Stockholm tentang Bahan Pencemar Organik yang Persisten dengan Undang-Undang Nomor 19 Tahun 2009 tentang Pengesahan Stockholm Convention on Persistent Organic Pollutants. Ratifikasi ini merupakan

43 Peraturan ini merubah sebagian PermenLH 04/2009. 
tindaklanjut dari penandatanganan Stockholm Convention on Persistent Organic Pollutants oleh Pemerintah Indonesia pada tanggal 23 Mei 2001. Konvensi ini terkait dengan pencemaran udara dari emisi pencemar organik yang persisten seperti dioxin dan furan..$^{44}$

Penanggulangan dan Pemulihan. PP 41/1999 memberikan mandat perlunya pedoman teknis penanggulangan dan pemulihan pencemaran udara, ${ }^{45}$ namun pedoman teknis tersebut belum pernah diterbitkan. Pada tahun 2011, Kementerian Lingkungan Hidup kemudian menerbitkan Peraturan Menteri Negara Lingkungan Hidup No. 13 Tahun 2011 Tentang Ganti Kerugian Akibat Pencemaran dan/atau Kerusakan Lingkungan Hidup yang kemudian direvisi dengan Peraturan Menteri Negara Lingkungan Hidup Nomor 07 Tahun 2014 tentang Kerugian Lingkungan Hidup Akibat Pencemaran dan / atau Kerusakan Lingkungan Hidup. Sebagian materi muatan peraturan ini berkaitan dengan penanggulangan dan pemulihan.

Pelestarian Fungsi Atmosfer. Berdasarkan UU 32/2009, pelestarian fungsi atmosfer meliputiupaya mitigasi dan adaptasi perubahan iklim, upaya perlindungan lapisan ozon, dan upaya perlindungan terhadap hujan asam. ${ }^{46}$ Pada tahun 2009 juga disahkan Undang-Undang Nomor 31 Tahun 2009 tentang Meteorologi, Klimatologi dan Geofisika yang didalamnya juga mengatur mengenai mitigasi dan adaptasi perubahan iklim. ${ }^{47}$ Dalam rangka mitigasi perubahan iklim, pada tahun 2011 diterbitkan Peraturan Presiden Republik Indonesia Nomor 61 Tahun 2011 Tentang Rencana Aksi Nasional Penurunan Emisi Gas Rumah Kaca.Upaya perlindungan lapisan ozon pada periode ini dilakukan dengan penerbitan Peraturan Menteri Negara Lingkungan Hidup Nomor 35 Tahun 2009 tentang Pengelolaan Halon.

Pengembangan Kapasitas Daerah. Upaya pengembangan kapasitas daerah di bidang pengendalian pencemaran udara ditandai dengan terbitnya Peraturan

44 Republik Indonesia, Undang-Undang Republik Indonesia Nomor 19 Tahun 2009 Tentang Pengesahan Stockholm Convention On Persistent Organic Pollutants (Konvensi Stockholm Tentang Bahan Pencemar Organik Yang Persisten), 2009.

45 Peraturan Pemerintah Nomor 41 Tahun 1999 Tentang Pengendalian Pencemaran Udara, n.d. Pasal 25 (2).

46 Republik Indonesia, Undang-Undang Nomor 32 Tahun 2009 Tentang Perlindungan Dan Pengelolaan Lingkungan Hidup, 2009. Pasal 57 (4).

47 Undang-Undang Nomor 31 Tahun 2009 Tentang Meteorologi, Klimatologi Dan Geofisika, 2009. Pasal 65-67. 
Menteri Negara Lingkungan Hidup No. 12 Tahun 2010 Tentang Pelaksanaan Pengendalian Pencemaran Udara di Daerah. Peraturan Menteri yang bertujuan untuk memberikan pedoman bagi pemerintah provinsi dan pemerintah kabupaten/ kota dalam melaksanakan pengendalian pencemaran udara tersebut mengatur pedoman mengenai: (a) penetapan baku mutu udara ambien; (b) penetapan status mutu udara ambien daerah; (c) penetapan baku mutu emisi, baku mutu emisi gas buang, dan baku mutu gangguan; (d) pelaksanaan koordinasi operasional pengendalian pencemaran udara; dan (e) koordinasi dan pelaksanaan pemantauan kualitas udara. Peraturan Menteri tersebut merupakan norma, standar, prosedur, dan kriteria (NSPK) yang merupakan penjabaran Pasal 9 Peraturan Pemerintah Nomor 38 Tahun 2007 tentang Pembagian Urusan Pemerintahan Antara Pemerintah, Pemerintahan Daerah Provinsi, dan Pemerintahan Daerah Kabupaten/Kota.

Pada saat artikel ini ditulis, pemerintah sedang mempersiapkan Rancangan Peraturan Pemerintah tentang Pengelolaan Kualitas Udara sebagai pelaksanaan dariUU32/2009. Draft tersebut berisi ketentuan umum, perencanaan, pemanfaatan, pengendalian, pemeliharaan, pengelolaan informasi, pengawasan dan sanksi administrasi serta pembiayaan. ${ }^{48}$

Dari uraian tersebut terlihat bahwa perkembangan yang ada pada periode ini menegaskan diterapkannya pendekatan bauran (policy mixes) dalam pengendalian pencemaran termasuk pencemaran udara. Penguatan instrumen CAC melalui pengaturan baku mutu emisi, baku mutu udara ambien, Amdal, izin lingkungan sebagai prasyarat izin usaha, pengawasan, sanksi administrasi serta sanksi pidana. Demikian juga dengan pendekatan LDC melalui pengaturan sanksi perdata (ganti rugi dan strict liability) dalam UU 32/2009.Untuk sumber tidak bergerak instrumen CAC dan LDC ini dibaurkan dengan instrumen E\&I berupa program PROPER dan standar kompetensi penanggung jawab pengendalian pencemaran udara.UU 32/2009 sebenarnya memungkinkan dikembangkannya instrumen ekonomi dan instrumen manajemen serta perencanaan (M\&P) melalui keterkaitan dengan tata ruang dan konsep ekoregion. Dengan demikian respon terhadap faktor pemicu (driving forces), khususnya pada aspek kesesuaian antara penataan ruang dengan upaya pengelolaan kualitas udara dapat lebih dielaborasi. Respon terhadap dampak

48 "DRAFT RPP UDARA," accessed May 5, 2016, http://proper.menlh.go.id/portal/ filebox/130423095940DRAFT\%20RPP\%20UDARA.pdf. 
(impacts),juga dapat dielaborasi dengan memberikan perhatian yang memadai pada pemantauan dampak pencemaran udara terhadap kesehatan masyarakat serta keterkaitan antara pencemaran udara dengan terjadinya hujan asam. ${ }^{49} \mathrm{Hal}$ ini akan mendukung dan terkait dengan instrumen LDC yang berkaitan dengan mekanisme ganti rugi akibat pencemaran udara.

\section{Simpulan dan Rekomendasi}

Berdasarkan uraian pada bagian-bagian sebelumnya, dikaitkan dengan pokok permasalahan yang dicoba diulas dalam tulisan ini, dapat disimpulkan beberapa hal sebagai berikut:

a. Evolusi pengaturan kualitas udara di Indonesia berkembang seiring dengan meningkatnya kesadaran dan perhatian pemerintah serta masyarakat terhadap masalah lingkungan hidup termasuk kualitas udara. Dalam tulisan ini diindikasikan dengan bertambahnya jumlah peraturan serta perjanjian lingkungan internasional yang diratifikasi. Perkembangan yang cukup signifikan terjadi setelah diundangkannya UU 4/1982 dan dibentuknya kementerian khusus yang menangani lingkungan hidup pada tahun 1978. Hal ini menunjukan adanya pengaruh faktor keberadaan lembaga pelaksana (implementing agency) terhadap perkembangan regulasi pengelolaan kualitas udara. Meskipun demikian, upaya pertama untuk mensistematisasikan pengaturan mengenai pengendalian pencemaran udara baru dapat dilakukan pada tahun 1999 dengan dikeluarkannya PP 41/1999. Seperti ditunjukan pada periode-periode awal, peranan pemerintah daerah juga cukup penting, dan perlu terus mendapat perhatian dalam konteks otonomi daerah.

b. Instrumen kebijakan yang diterapkan juga semakin berkembang seiring dengan bertambahnya jumlah peraturan. Instrumen kebijakan yang diatur telah bergeser dari hanya menggunakan pendekatan tradisional command and control ke arah bauran kebijakan (policy mixes) dengan menerapkan intrumen liability and damage compensation, dan instrumen edukasi dan informasi. Namun, instrumen ekonomi dan instrumen perencanaan dan manajemen

49 Eko Cahyono, "Pengaruh Hujan Asam Pada Biotik Dan Abiotik," Berita Dirgantara LAPAN Vol 8 (September 3, 2007): 48-51. 
belum banyak terelaborasi dalam konteks pengelolaan kualitas udara.

c. Respon kebijakan yang termuat dalam peraturan berkembang dari hanya mengatasi tekanan, kepada upaya mengatasi kondisi kualitas udara dan pada sebagian dampak. Sementara itu, respon terhadap faktor pemicu dan keseluruhan dampak belum banyak terelaborasi.

Dari kesimpulan tersebut dapat diajukan beberapa rekomendasi sebagai berikut:

a. Penguatan lembaga pelaksana (implementing agency) pada tingkat pusat dan daerah perlu terus dilakukan. Kompleksitas pengelolaan kualitas udara (multi sumber-multi pencemar-multi dampak) juga mengisyaratakan dengan jelas perlunya koordinasi antar lembaga secara vertikal maupun horizontal.Terkait hal ini, artikel ini masih dapat dikembangkan lebih lanjut dengan meneliti perkembangan regulasi pengelolaan kualitas udara di daerah (Provinsi dan Kabupaten/Kota) serta sektor-sektor terkait seperti Perhubungan, Perindustrian, Energi dan Sumber Daya Mineral, Kesehatan serta sektor lainnya yang belum sepenuhnya tercakup dalam tulisan ini. Analisis lebih lanjut dapat dilakukan dengan melihat perkembangan tingkat sinkronisasi peraturan perundang-undangan tersebut baik secara horizontal (dalam tingkat peraturan yang sama) maupun secara vertikal (antara peraturan yang lebih rendah dengan peraturan yang lebih tinggi. Dengan demikian dapat dilihat tingkat koherensi kebijakan yang diterapkan, karena kualitas pengaturan tidak hanya bisa dilihat dari segi jumlah.

b. Seiring dengan meningkatnya tantangan dalam pengelolaan kualitas udara, diperlukan kerangka pengaturan yang lebih komprehensif yang dapat merespon faktor pemicu (driving forces), tekanan (pressures), kondisi kualitas udara (state) dan dampak (impacts) yang terjadi. Peraturan Pemerintah yang baru sebagai pelaksanaan UU 32/2009 diharapkan dapat memberikan landasan hukum yang lebih komprehensif tersebut. Kompleksitas pengelolaan kualitas udara mungkin akan membuat peraturan pelaksanaan UU 32/2009 tidak bisa mewadahi semuanya. Oleh karena itu, rekomendasi pada bagian (a) di atas perlu diperhatikan. 
c. Instrumen kebijakan lainnya seperti instrumen ekonomi, pendekatan sukarela (voluntary approach) dan pendekatan perencanaan dan manajemen (management and planning) perlu dielaborasi lebih lanjut. Penerapan berbagai instrumen kebijakan tersebut perlu dilakukan dalam pendekatan kebijakan campuran (policy mixes) yang koheren (saling terkait dan berhubungan dalam suatu sistem yang logis).Penelitian mengenai efektivitas pengaturan dan instrumen kebijakan yang dimuatnya juga perlu dilakukan untuk melihat sejauh mana pengaturan tersebut dapat mengatasi perkembangan tantangan yang dihadapi sebagai respon terhadap faktor pemicu (driving forces), tekanan (pressures), kondisi kualitas udara (state) dan dampak (impacts) yang terjadi. Penelitian semacam ini idealnya dilakukan dengan pendekatan multidisiplin yang tidak hanya menggunakan disiplin ilmu hukum namun juga disiplin ilmu lainnya yang relevan. 


\section{DAFTAR PUSTAKA}

Hamzah, Andi. 1997. Penegakan Hukum Lingkungan. Jakarta: Sapta Arta Jaya.

Maria Persson , Åsa. 2007. “Choosing Environmental Policy Instruments: Case Studies Of Municipal Waste Policy In Sweden And England." A thesis submitted to the Department of Geography and Environment of the London School of Economics and Political Science for the degree of Doctor of Philosophy.

"Badan Pusat Statistik." Accessed May 3, 2016. http://www.bps.go.id/ linkTabelStatis/view/id/1413.

Sukana, Bambang and Naseh , Syahrudji. 1993. "Pencemaran Udara Di DKI Jakarta (Review)."Media Litbangkes III, Nomor 4: 6-12.

Dede Nurdin Sadat, Fathi Hanif, Lucentezza Napitupulu, Moekti H. Soejachmoen, Prayekti Murhajanti, Shanty M.F. Syahril, and Sukanda Husin. 2003. Udara Bersih Hak Kita Bersama. Jakarta: Pelangi.

“DRAFT RPP UDARA.” Accessed May 5, 2016. http:/ / proper.menlh.go.id/ portal/ filebox/130423095940DRAFT\%20RPP\%20UDARA.pdf.

Keputusan Gubernur KDKI Jakarta No. 587 Tahun 1980 Tentang Penetapan Kriteria Ambient Kualitas Udara Dan Kriteria Ambient Bising Dalam Wilayah DKI Jakarta, 1980.

Keputusan Menteri Negara Kependudukan Dan Lingkungan Hidup Nomor: Kep-02/ Menklh/I/1988 Tentang Pedoman Penetapan Baku Mutu Lingkungan, 1988.

Keputusan Menteri Negara Lingkungan Hidup Nomor 45 Tahun 1997 Tentang Indeks Standar Pencemar Udara, 1997.

Keputusan Presiden Republik Indonesia Nomor 35 Tahun 1978 Tentang Perubahan, Keputusan Presiden Nomor 28 Tahun 1978 Tentang Kedudukan, Tugas Pokok, Fungsi, Dan Tatakerja Menteri Negara Penertiban Aparatur Negara, Menteri Negara Pengawasan Pembangunan Dan Lingkungan Hidup, Menteri Negara Riset Dan Teknologi Serta Susunan Organisasi Stafnya, 1978. 
“Kesimpulan Kelompok Substansi Udara Bersih.” Accessed May 3, 2016. http:/ / langitbiru.menlh.go.id/upload/program/pdf/kes-rakor.pdf.

Hardjasoemantri, Koesnadi. 2009. Hukum Tata Lingkungan. 8th ed. Yogyakarta: Gadjah Mada University Press.

Syarif, La Ode Muhammad. 2001. The Implementation of International Responsibilities for Atmospheric Pollution: A Comparison Between Indonesia and Australia. Jakarta: ICEL.

M. Didin Khaerudin, Fitri Harwati, John H.P. Tambun Mulia, and Dian Sugiarti. 2009. Kota Di Persimpangan Jalan: Pedoman Perancangan Strategi Pengendalian Emisi Dari Sektor Transportasi Jalan Di Kawasan Perkotaan. Jakarta: Kementerian Lingkungan Hidup.

OECD. 2001. Sustainable Development Critical Issues: Critical Issues. OECD Publishing. Peraturan Menteri Dalam Negeri Nomor 1 Tahun 1985 Tentang Tata Cara Pengendalian Pencemaran Bagi Perusahaan-Perusahaan Yang Mengadakan Penanaman Modal Menurut Undang-Undang Nomor 1 Tahun 196 Dan Undang-Undang Nomor 6 Tahun 1968., 1985.

Peraturan Pemerintah Nomor 41 Tahun 1999 Tentang Pengendalian Pencemaran Udara, n.d.

Peraturan Pemerintah Nomor 44 Tahun 1993 Tentang Kendaraan Dan Pengemudi, 1993. Peraturan Pemerintah RI Nomor 04 Tahun 2001 Tentang Pengendalian Kerusakan Dan Atau Pencemaran Lingkungan Hidup Yang Berkaitan Dengan Kebakaran Hutan Dan Atau Lahan, 2001.

Republik Indonesia.Keputusan Menteri Perindustrian No. 12/M/SK/1/78 Tentang Pencegahan Dan Penanggulangan Pencemaran Lingkungan Sebagai Akibat Dari Usaha Industri, 1978.

- - - Undang-Undang Nomor 4 Tahun 1982 Tentang Pokok-Pokok Pengelolaan Lingkungan Hidup, 1982.

- - - Undang-Undang Nomor 26 Tahun 2007 Tentang Penataan Ruang, 2007.

- - - . Undang-Undang Nomor 32 Tahun 2009 Tentang Perlindungan Dan Pengelolaan 
Lingkungan Hidup, 2009.

- - - Undang-Undang Republik Indonesia Nomor 19 Tahun 2009 Tentang Pengesahan

Stockholm Convention On Persistent Organic Pollutants (Konvensi Stockholm Tentang Bahan Pencemar Organik Yang Persisten), 2009.

Soedomo, Moestikahadi. 1999. Kumpulan Karya Ilmiah Mengenai Pencemaran Udara. Bandung: Penerbit ITB.

Surat Keputusan Gubernur Propinsi DKI Jakarta No. 670/2000 Tanggal 28 Maret 2000 Tentang Penetapan Baku Mutu Emisi Sumber Tidak Bergerak Di Propinsi DKI Jakarta, 2000.

Undang-Undang Nomor 31 Tahun 2009 Tentang Meteorologi, Klimatologi Dan Geofisika, 2009.

Undang-Undang Gangguan (Hinderordonnantie) Hinder Ordonnantie Staatsblad Tahun 1926 Nomor 226, 1926.

United Nations. 1972. "Report of the United Nations Conference on the Human Environment." United Nations. http://www.un-documents.net/aconf4814r1.pdf.

Vaz, S.G., T. Ribeiro, and EEA. 2001. Reporting on Environmental Measures: Are We Being Effective? Environmental Issue Report. European Environment Agency. http:/ / www.eea.europa.eu/publications/rem/issue25.pdf. 